\title{
Analisis Faktor Lingkungan Sekolah yang Mempengaruhi Motivasi Belajar Siswa Sekolah Dasar
}

\author{
Nurul Sa'adah ${ }^{1}$, Syahrial ${ }^{2}$, Sumianto ${ }^{3 *}$ \\ ${ }^{123}$ (Universitas Pahlawan Tuanku Tambusai).
}

\author{
${ }^{*}$ Corresponding Author. E-mail: ${ }^{1}$ nuruelsaadah@gmail.com ${ }^{2}$ antoeglos@gmail.com
}

\begin{abstract}
Abstrak
Penelitian ini membahas tentang analisis faktor lingkungan sekolah yang mempengaruhi motivasi belajar siswa sekolah dasar. Studi ini bertujuan untuk mengetahui mengenai permasalahan: Faktor lingkungan sekolah yang mempengaruhi motivasi belajar siswa sekolah dasar, di kelas V SDN 007 Suka Maju, narasumber dalam penelitian ini berjumlah 14 orang yang beruba 11 orang siswa dan 3 orang guru. Penelitian ini merupakan penelitian deskriptif kualitatif yang mengunakan teknik analisis kualitatif, dengan variabel bebas lingkungan sekolah, sedangkan variabel terikatnya adalah motivasi belajar. Pengumpulan data dengan mengunakan instrumen observasi, wawancara, dan dokumentasi. Observasi dan wawancara digunakan untuk memperoleh data lingkungan sekolah dan motivasi belajar siswa. Teknik analisis datanya dengan langkah-langkah: Reduksi data, penyajian data, dan penarikan kesimpulan. Hasil ini menunjukan bahwa: 1) Faktor lingkungan sekolah yang mempengaruhi Motivasi belajar siswa kelas V SDN 007 Suka Maju dipengaruhi oleh lima faktor lingkungan sekolah yaitu metode mengajar, keadaan gedung, relasi guru dengan siswa, relasi siswa dengan siswa, dan alat pembelajaran atau media belajar, 2) Dari kelima faktor tersebut yang paling dominan mempengaruhi motivasi belajar siswa adalah faktor metode mengajar, dan media belajar. Yang mana dengan adanya metode mengajar dan media yang bervariasi bisa mempengaruhi motivasi belajar siswa.
\end{abstract}

Kata Kunci: Lingkungan Sekolah,Motivasi Belajar.

\section{ANALYSIS OF SCHOOL ENVIRONMENTAL FACTORS THAT INFLUENCE THE LEARNING MOTIVATION OF ELEMENTARY SCHOOL STUDENTS}

\begin{abstract}
This study discusses the analysis of school environmental factors that affect the learning motivation of elementary school students. This study aims to find out about the problems: School environmental factors that affect the learning motivation of elementary school students, in class V SDN 007 Suka Maju, the resource persons in this study amounted to 14 people consisting of 11 students and 3 teachers. This research is a qualitative descriptive study that uses qualitative analysis techniques, with the independent variable being the school environment, while the dependent variable is learning motivation. Collecting data using the instruments of observation, interviews, and documentation. Observations and interviews were used to obtain data on the school environment and students' learning motivation. The data analysis technique uses the following steps: data reduction, data presentation, and conclusion drawing. These results indicate that: 1) School environmental factors that influence the learning motivation of fifth grade students at SDN 007 Suka Maju are influenced by five school environmental factors, namely teaching methods, building conditions, teacherstudent relations, student-student relations, and learning tools or learning media. , 2) Of the five factors that most dominantly affect student learning motivation is the factor of teaching methods, and learning media. Which with the various teaching methods and media can affect students' learning motivation.
\end{abstract}

Keywords: school environment, learning motivation 


\section{A. Pendahuluan}

Undang-Undang Nomor 20 Tahun 2003 pasal 1 ayat (1) pendidikan adalah usaha sadar dan terencana untuk mewujudkan suasana belajar dan proses pembelajaran agar peserta didik secara aktif mengembangkan potensi dirinya untuk memiliki kekuatan spiritual keagamaan, pengendalian diri, kepribadian, kecerdasan, akhlak mulia, serta keterampilan yang diperlukan dirinya, masyarakat, bangsa dan negara. Peraturan pemerintahan Nomor 17 Tahun 2010 pasal 1 ayat (2) Penyelenggaraan pendidikan adalah kegiatan pelaksanaan komponen sistem pendidikan pada satuan atau program pendidikan pada jalur, jenjang, dan jenis pendidikan agar proses pendidikan dapat berlangsung sesuai dengan tujuan pendidikan nasional.

Pendidikan merupakan suatu kegiatan yang universal dalam kehidupan manusia, karena dimanapun dan kapan pun didunia terdapat pendidikan. Pada hakikatnya pendidikan suatu usaha manusia untuk memenusiakan manusia itu sendiri, untuk memuliakan manusia. Dikehendaki oleh subjek belajar itu dapat tercapai". Sumianto (2018:03) Belajar merupakan aktifitas yang dilakukan seseorang dengan berinteraksi dengan lingkungan untuk mencapai tujuan tertentu berupa perubahan sikap, hasil belajar, dan perubahan tingkah laku kearah yang lebih baik. adanya pengkondisian siswa dalam melakukan aktivitas yang bermakna.

Dengan memiliki aktivitas belajar yang baik akan menciptakan suasana kelas menjadi kondusif, dimana siswa dapat melibatkan kemampuannya secara maksimal yang mengakibatkan terbentuknya pengetahuan dan keterampilan yang mengarah pada peningkatan prestasi. Untuk mencapai peningkatan prestasi secara akademik menurut Slameto (2018:02) menyatakan bahwasanya pencapaian akademik yang tinggi dibutuhkan tingkat belajar yang tinggi pula dan untuk dapat belajar dengan baik diperlukan proses dan motivasi yang baik pula, Sehingga dalam kegiatan itu jika tidak melalui proses dengan didasari motif yang baik, atau mungkin kerena rasa takut, terpaksa atau sekedar seremonial, jelas akan menghasilkan hasil belajar yang semu, tidak otentik dan tidak tahan lama.

Mencapai motivasi belajar menurut Uno (2019:01) memberikan dorongan dasar yang menggerakkan seseorang bertingkah laku. Dorongan ini berada pada diri seseoarang untuk melakukan sesuatu yang sesuai dengan dorongan dalam dirinya. oleh karena itu, perbuatan seseorang yang didasarkan atas motivasi tertentu mengandung tema sesuai dengan motivasi yang mendasarinya. Motivasi juga dapat dikatakan sebagai perbedaan antara dapat melaksanakan dan mau melaksanakan. Motivasi lebih dekat pada mau melaksankan tugas untuk mencapai tujuan. Motivasi merupakan kekuatan, baik dari dalam maupun dari luar yang mendorong seseoarang untuk mencapai tujuan tertentu yang telah ditetapkan sebelumnya.

Sardiman (2016:89) motivasi belajar dapat timbul karena faktor intrinsik dan faktor ekstrinsik. Faktor intrinsiknya berupa hasrat dan keinginan untuk berhasil dan dorongan kebutuhan belajar, harapan akan cita-cita. Sedangkan faktor ekstrinsiknya adalah adanya penghargaan lingkungan yang kondusif dan kegiatan belajar yang menarik. Lingkungan yang kondusif dan kegiatan belajar yang menarik dapat membangkitkan motivasi belajar siswa. Seorang siswa jika tidak memiliki motivasi dalam belajar maka akan berpengaruh pada menurunnya hasil belajar dan prestasisiswa. Motivasi memiliki peran penting dalam proses belajar setiap siswa. Siswa yang memiliki motivasi akan dapat meningkatkan prestasi dalam belajarnya.

Slameto (2018:60) Salah satu pengaruh yang dapat mendukung suatu motivasi belajar yaitu faktor lingkungan yang kondusif yaitu lingkungan Sekolah. Lingkungan sekolah merupakan salah satu faktoryang mempengaruhi motivasi belajar siswa. Lingkungan sekolah seperti para guru, staf administrasi, dan teman-teman sekelas dapat mempengaruhi motivasi belajar siswa. Lingkungan sekolah secara fisik meliputi keadaan fisik sekolah, sarana dan prasarana di dalam kelas, keadaan gedung sekolah dan sebagainya. Faktor lingkungan sekolah yang mempengaruhi belajar meliputi metode mengajar, kurikulum, relasi guru dengan siswa, relasi siswa dengan siswa, disiplin sekolah, pelajaran dan waktu sekolah, standar pelajaran diatas ukuran, keadaan gedung, metode belajar dan tugas rumah.

Lingkungan sekolah yang nyaman dan bersih dapat menimbulkan kenyamanan dalam pembelajaran, karena siswa dapat lebih berkonsentrasi serta kreatif sehingga dapat meningkatkan motivasi siswa untuk belajar. Selain kenyamanan siswa dalam belajar di sekolah, fasilitas yang memadai juga dapat mempengaruhi motivasi belajar siswa. Sarana dan prasarana sekolah harus mampu mendukung dan memberikan pelayanan dalam proses belajar siswa dan mengajar guru. Dalam hal ini sudah barang tentu peran 
guru sebagai salah satu komponen yang ada dalam lingkungan sekolah sangatlah penting.

Sardiman (2016:77) Bagaimana guru melakukan usaha-usaha untuk dapat menumbuhkan dan memberikan motivasi agar anak didiknya melakukan aktivitas belajar dengan baik. Adapun yang merupakan ciri lingkungan sekolah yang baik ialah terjadinya komunikasi yang baik antara guru dengan siswa, siswa dengan siswa dengan tidak adanya permusuhan diantara mereka, dan dalam proses pembelajaran guru selalu memberikan media pemebelajaran yang menunjang proses pembelajaran seperti tersedianya alat peraga yang cukup contohnya alat peraga berhitung, olahraga dan lain sebagainya, selain itu ciri sekolah yang baik juga memiliki halaman sekolah yang cukup, pohon-pohon yang rindang, taman yang indah dan lain sebagainya.

Lingkungan sekolah memiliki peranan penting dalam pembentukan perilaku sosial siswa, sehingga dari tujuan pendidikan dapat diwujudkan secara maksimal. Semua warga sekolah harus dapat melaksanakan apa yang menjadi tugas daripada dirinya. Kepala sekolah bertindak sebagai kepala sekolah yang dapat mengawasi dan membuat kebijakan bagaimna program sekolah dapat terealisasi.

Guru sebagai model keteladan untuk para siswanya, serta masyarakat disekitar lingkungan sekolah dapat meninjau bagaimana kegiatan kependidikan di sekolah tersebut. Sebagai makhluk sosial, seorang individu sejak lahir hingga sepanjang hayatnya senantiasa berhubungan dengan individu lainnya atau dengan kata lain melakukan relasi interpersonal. Dalam relasi interpersonal itu ditandai dengan berbagai aktivitas tertentu, baik aktivitas yang dihasilkan berdasarkan naluriah semata atau justru melalui proses pembelajaran tertentu.

Namun pada kenyataanya berdasarkan hasil observasi dikelas V SDN 007 Suka Maju saat proses pembelajaran terjadi, didapatkan informasi dari melihat fakta lapangan dan hasil observasi gejala motivasi belajar yang rendah didapatkan informasi hasil yaitu adanya beberapa siswa yang tidak tidak mengerjakan tugas yang diberikan oleh guru, ketika diberi kesempatan, tidak memperhatikan (menyimak) pelajaran atau materi yang sedang disampaikan guru, mencontek pekerjaan temannya, mengobrol dengan temenya saat proses belajar mengajar berlangsung. Dengan melihat faktor-faktor penyebab kurangnya motivasi dalam belajar pada siswa tersebut, cukup jelas mengahambat proses pembelajaran dikelas. Hal ini tidak dapat dibiarkan begitu saja dan perlu mendapatkan perhatian khusus karena jika siswa tidak semangat dan tidak termotivasi dalam belajar siswa tersebut akan mengalami penurunan nilai dan untuk jangka panjang dapat dibayangkan siswa tersebut tidak memiliki motivasi yang tinggi bagaimana siswa tersebut akan bertahan hidup.

Kemampuan siswa untuk bertahan hidup seperti yang dicita- citakan kurikulum 13 bahwasanya pembelajaran itu harus memberikan bekal pengalaman hidup dan juga siswa memberikan pembekalan pengalaman hidup untuk siswa agar mampu menemukan dan menentukan pemecahan masalah yang dihadapinya baik sekarang maupun dimasa yang akan datang, dengan motivasi dan kecakapan hidup yang memadai diharapkan siswa mampu menemukan sesuatu yang baru dan bahkan mereka dapat menjadi solusi bagi masyarakat yang ada ditempat tinggalnya. Dikawatirkan apabila siswa tidak memiliki motivasi yang kuat dalam dirinya kedepanya siswa ketika menghadapi permasalahan akan mudah putus asa dan mudah untuk mengambil jalan pintas.

Sesuai dengan rumusan masalah diatas maka tujuan penelitian ini adalah: maka tujuan dari penelitian ini adalah untuk mengetahui Faktor lingkungan sekolah yang mempengaruhi motivasi belajar siswa sekolah dasar, di kelas V SDN 007 Suka Maju.

Berdasarkan uraian yang telah dibahas sebelumnya ini perlu mendapatkan perhatian kusus agar peristiwa-peristiwa yang serupa tidak terulang kembali, untuk itu pada penelitian ini penulis mencoba menemukan faktor lingkungan sekolah untuk meningkatkan motivasi belajar dengan judul "Analisis Faktor Lingkungan Sekolah Yang Mempengaruhi Motivasi Belajar Siswa Sekolah Dasar".

\section{B. Metode}

Jenis penelitian yang di gunakan oleh penulis pada penelitian ini adalah kualitatif deskriptif. Dengan Metode yang di gunakan dalam penelitian ini yaitu metode deskripsi dengan pendekatan secara kualitatif. Alasan peneliti melakukan penelitian dengan pendekatan kualitatif karena sesuai dengan sifat dan tujuan peneliti yang ingin di peroleh bukan menguji hipotesis tetapi berusaha mendapat gambaran yang nyata mengenai faktor lingkungan Sekolah yang mempengaruhi Motivasi belajar siswa kelas V SDN 007 Suka Maju.

Tempat penelitian akan di lakukan di SD Negeri 007 Suka Maju, Kabupaten Kampar. Waktu penelitian ini di rencanakan selama 6 bulan ( Maret sampai 
dengan Juli 2021) terhitung sejak proposal penelitian di seminarkan di lanjutkan dengan penulisan skripsi sampai dengan ujian sarjana.

\section{a. Data Primer}

Menurut Arikunto data primer adalah data dalam bentuk verbal atau kata-kata yang diucapkan secara lisan, gerak-gerik atau perilaku yang dilakukan oleh subjek yang dapat dipercaya, yakni subjek penelitan atau informan yang berkenaan dengan variabel yang diteliti atau data yang diperoleh dari responden secara langsung. Adapun sumber data primer dalam penelitian ini diperoleh dari hasil wawancara dan dokumentasi, yang didapat dari siswa dan guru diSDN 007 Suka Maju.

\section{b. Data Sekunder}

Data sekunder adalah data yang diperoleh dari teknik pengumpulan data yang menunjang data primer. Dalam penelitian ini diperoleh dari hasil dokumentasi yang dilakukan oleh peneliti. Dapat dikatakan data sekunder ini bisa berasal dari dokumen-dokumen seperti tabel, hasil observasi, wawancara, foto dan lainlain .

Contohnya saja pada saat peneliti melakukan penelitian diSD menggunakan catatan-catatan yang mana isinya mencatatan tentang hasil dari wawancara tentang motivasi belajar siswa pada saat siswa dan guru melakukan proses pembelajaran dan diluar jam pelajaran.

Dalam penelitian kualitatif narasumber (informan) sangat penting, karena bagi peneliti narasumber adalah orang yang memberikan informasi berupa data-data yang akan kita ambil dalam penelitian. Narasumber dalam penelitian ini berjumlah 5 orang. Semua narasumber tersebut merupakan kepala sekolah dan guru SDN 007 Suka Maju.

Teknik pengumpulan data dalam penelitian ini mengunakan observasi yang mana Observasi sangat sesuai digunakan dalam penelitian yang berhubungan dengan kondisi dan interaksi belajar mengajar, tingkah laku sampai interaksi kelompok. Kelebihan teknik ini adalah data yang diperoleh lebih dapat dipercaya karena dilakukan atas pengamatan sendiri dengan berkomunikasi dan berinteraksi. Sehingga peneliti mengadakan observasi secara langsung di lapangan untuk mengetahui kondisi yang terjadi di lembaga pendidikan tepatnya di lingkungan SDN 007 Suka Maju - Metode ini digunakan peneliti untuk mengamati situasi latar alami kegiatan pembelajarantersebut.
Wawancara pada penelitian ini mengunakan wawancara tak berstruktur, yang mana menurut Sugiyono (2018:320) wawancara takberstruktur adalah wawancara yang bebas di mana peneliti tidak mengunakan pedoman wawancara yang telah tersusun secara sistematis dan lengkap untuk pengumpulan datanya pedoman wawancara yang digunakan hanya berupa garis garis-garis besar permasalahan yang akan ditanyakan. Peneliti ini diambil dengan carawawancara kepada siswa dikelas V SDN 007 Suka Maju.

Dokumentasi adalah cara lain untuk memperoleh data dari responden. Pada teknik ini, peneliti dimungkinkan memperoleh informasi dari bermacam-macam sumber tertulis atau dokumen yang ada pada responden atau tempat di mana responden bertempat tinggal atau melakukan kegiatan sehariharinya. Dalam penelitian ini metode dokumentasi yang digunakan adalah foto kegiatan pembelajaran, hasil wawancara dan observasi.

Teknik analisis data dalam penelitian ini ada tiga yaitu:

\section{a. Reduksi data}

Mereduksi data berarti merangkum, memilih halhal yang pokok, memfokuskan pada hal- hal yang penting di cari tema dan polanya. Dengan demikian data yang telah direduksi akan memberikan gambaran yang lebih jelas, dan mempermudah peneliti untuk melakukan pengumpulan data selanjutnya, dan mencarinya bila diperlukan. Penelitian dalam mereduksi data akan dibantu oleh pembimbing karena peneliti baru pertama melakukan penelitian kualitatif.

\section{b. Penyajian data}

Setelah data direduksi, maka selanjutnya adalah menyajikan data, penyajian data dalam penelitian kualitatif berbentuk uraian singkat. Berdasarkan yang telah dipahami bahwa penyajian data diperoleh setelah dirangkum berupa bentuk uraian, bukti fisik yang kemudian diolah dalam bentuk uraiannya. Penyajian data akan mempermudah peneliti untuk memahami apa yang terjadi, merencanakan kerja selanjutnya berdasarkan apa yang telah di pahami tersebut.

\section{c. Penarikan kesimpulan}

Penarikan kesimpulan merupakan hasil
penelitian yang menjawab fokus penelitian berdasarkan hasil analisis data. Adapun kesimpulan awal yang dikemukakan masih bersifat sementara dan akan berubah bila ditemukan bukti-bukti yang kuat yang mendukung pada tahap berikutnya. 


\section{Hasil dan Pembahasan}

Temuan hasil penelitian dan pembahasan dibawah ini merupakan hasil yang diperoleh melalui proses observasi, wawancara dan dokumentasi selama melaksanakan penelitian.

Wawancara dilakukan terhadap 14 responden, yang masing-masing terdiri dari 3 orang guru yang masuk ke kelas V dan 11 orang siswa kelas V SDN 007 Suka Maju. Data hasil wawancara tidak mungkin dapat mengungkapkan semua aktivitas yang menjadi fokus penelitian, untuk itu peneliti juga melakukan observasi langsung terhadap lingkungan yang ada didalam sekolah serta kegiatan pada saat proses pembelajaran dikelas dan diluar kelas.

Observasi ini peneliti laksanakan di kelas dan diluar kelas dengan rentang waktu 2-4 kali observasi. Hal ini di maksudkan agar hasil observasinya lebih kuat. Untuk memperkuat hasil wawancara dan observasi, peneliti melakukan telaah terhadap dokumentasi yang ada di SDN 007 Suka Maju.

\section{Faktor Lingkungan Sekolah}

\section{a. Metode Mengajar}

Berdasarkan hasil temuan observasi yang dilakuka lebih dari setangah bulan ditemukan bahwa metode mengajar yang digunakan guru dalam proses pembelajaran terlihat masih belum bervariasi seperti pada guru $Y$ yang mengunakan metode ceramah dan tanya jawab secara langsung, guru A karena guru tersebut merupakan guru olahraga disini guru tersebut selalu praktek langsung kelapangan yang mana membuat siswa bersemangat pada saat proses pembelajaran berlangsung, dan sedangkan guru $\mathrm{Z}$ guru tersebut banyak mengunakan metode seperti metode mengunakan metode diskusi, metode ceramah dan tanya jawab disini guru juga menyampaikann metode dengan vasih dan menguasai yang membuat siswa termotivasi dalam belajar.

Berdasarkan metode yang digunakan guru samasama masih mengunakan yang termasut metode tradisional, bukan berarti metode tradisional ini tidak baik namun disarankan guru menggunakan metode sesuai dengan materi ajar yang guru ajarkan atau sesuai karakteristik pelajaran yang sedang diajarkan. Pada guru $Y$ salah satu materi yang diajarkan adalah materi tentang organ dalam manusia seharusnya guru melaksanakan sesuai dengan metode mata pelajaran IPA bahwasanya didalam pembelajran IPA harusnya mengunakan metode pembelajaran yang menarik, hal ini sesuai dengan penelitian Realin bahwasnya pembelajaran IPA akan lebih bermakna jika disajikan dengan menarik dan mengunakan pendekatan, metode, serta alat peraga sebgaimana menurut piaget bahwa usia 7-12 tahun merupakan tingkat permulaan berfikirrasioanl dan mulai mengatur data kedalam hubungan-hubungan logis dan mendapatkan kemudahan dalam memanipulasi data dalam situasi pemecahan masalah. Untuk guru A disini guru mengunakan metode ceramah dan tanya jawab akan tetapi guru tersebut lebih sering mengunakan metode praktek secara langsung diluar kelas yang membuat siswa faham akan pelajaran yang diajrarkan guru. Hasil dokumentasi saat guru menggunakan metode ceramah:

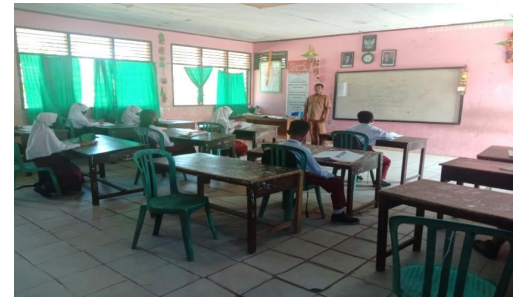

Sumber: dokumentasi penelitian

\section{Gambar.IV.3}

\section{Proses Pembelajaran Berlangsung}

Selain itu untuk pembelajaran dengan guru $Z$ salah satu yang diajarkan guru disini berupa tentang surat AT-TIN yang mana disitu guru mengajarkan tentang tarlilah pembacaan surat tersebut yang mana guru mengunakan metode pembelajran demostrasi, yang mana melalui metode demostrasi guru memberikan contoh lalu siswa mengikuti hal ini sudah benar sudah baik hal ini sesuai dengan teori yang dikemukakan oleh Nasih (2009: 63) Demonstrasi merupakan metode yang sangat efektif, sebab dapat membantu anak didik mencari jawaban dengan usaha sendiri berdasarkan fakta (data) yang benar. Demonstrasi yang dimaksud adalah suatu proses metode mengajar yang memperlihatkan bagaimana memperlihatkan proses terjadinya sesuatu.

Berdasarkan itu semua ada yang sudah cocok ada yang belum cocok metode yang mereka gunakan sebaiknya setiap pemebalajaran dimulai guru harus mengunakan metode pembelajaran yang bervariasi dan sesuai dengan pembelajaran yang akan diajarkan, karena dengan adanya metode yang bervariasi mampu memberikan motivasi belajar kepada siswa. Ini sesuai dengan penelitian Muhammad bahwasanya pengunaan variasi metode pembelajaran ternyata dapat berpengaruh terhadap motivasi belajar siswa. Motivasi belajar peserta didik akan berkembang jika disertai dengan implementasi keberagaman metode pemebelajaran. 
Jadi dapat dibahas, dengan adanya proses pembelajaran dengan menggunakan metode pembelajaran yang bervariasi akan memberikan dampak yang lebih bagus dalam motivasi belajar siswa kelas V SDN 007 Suka Maju, diantaranya guru akan mudah dalam mengajar dan peserta didik akan merasa lebih nyaman dan antusias saat materi berlangsung dan akan bersungguh-sungguh untuk belajar sehingga membangkitkan motivasi anak didik untuk mendapatkan prestasi yang lebih bagus dan unggul dalam pembelajaran. Sehingga proses pembelajaran dapat berjalan dengan baik, efektif dan juga efisien

\section{b.Kondisi Lingkungan Sekolah}

Berdasarkan teori yang dikemukakan Slameto (2018:54) mengatakan bahwsanya lingkungan sekolah merupakan kondisi seluruh yang ada di sekolah yang dapat mepengaruhi prestasi yang dicapainya, maka siswa dalam belajar dapat terpengaruh oleh lingkungan sekitar. Lingkungan yang aman, nyaman dan bisa disesuaikan sendiri dapat menumbuhkan dorongan untuk belajar. Sebaliknya lingkungan yang kurang menyenangkan seperti kegaduhan, kekacauan dan tidak bersih dapat mengganggu kapasitas untuk berkonsentrasi dan menumbuhkan keinginan untuk tidak belajar. Hasil dari observasi, wawancara, dan dokumentasi yang didapatkan dikelas V SDN 007 Suka Maju sebagai berikut:

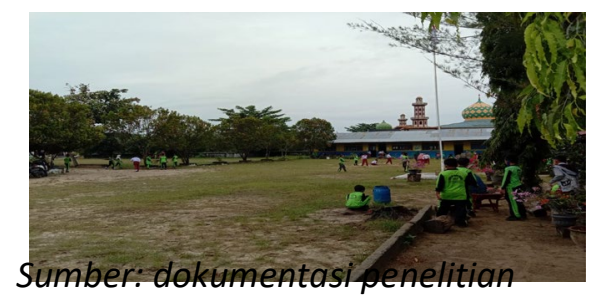

Gambar.IV.4

Kondisi lingkungan SDN 007 Suka Maju Siswa Bermain dihalaman Sekolah

Menunjukkan bahwasanya Kondisi sekolah dan lingkungan yang ada di sekitar sekolah cukup bersih. Di setiap depan kelas terdapat taman yang indah walaupun masih ada kelas yang belum terdapat taman akan tetapi sudah terlihat bahwasanya akan adanya taman yang dibuat untuk setiap kelasnya. Didekat lapangan upaca dan lapangan olahraga sudah terdapat pohon-pohon yang rindang yang membuat siswa bisa bermain disana dengan nyaman, serta kebersihannya juga cukup terjaga. Sekolah bersebelahan langsung dengan sebuah jalan. Kesibukan lalu lintas tidak menimbulkan suara bising yang mengganggu aktivitas belajar mengajar di dalam sekolah. untuk ruangan kelas
V nyaman yang mana di kelas tersebut sudah tersedia kipas angin walaupun hanya dua.

Pada lantai ruangan kelas $\mathrm{V}$ sudahlah keramik. Untuk tata tertib sekolah, terlihat sudah memiliki tata tertib sekolah yang di pasang didepan salah satu kelas SDN 007 Suka Maju. Sehingga semua orang dan siswa dapat melihat dan membaca tata tertib sekolah tersebut. Kelengkapan fasilitas, seperti meja, kursi, dan alat tulis lainnya sudah cukup memadai. Meskipun masih ada beberapa kursi dan meja yang seharunya diganti namun masih dipakai oleh siswa, dikarenakan masih belum mendapatkan meja yang baru dari pemerintah.

Ruangan untuk perpustakaan terletak bersebelahan dengan ruangan penjaga sekolah. Ruangan perpustakan bersebelahan dengan gudang penyimpanan kursi-kursih dan meja-meja yang sudah rusak. untuk ukuran ruangan perpustakaan sangat kecil, sehingga jika anak ingin membaca buku didalam ruangan tersebut sangat sempit dan tidak bisa menampung banyak siswa untuk membaca disana. Tetapi perpustakaan disana memiliki banyak jenis buku, mulai dari buku pendidikan, dongeng, hingga buku tata boga.

SDN 007 Suka Maju memiliki 1 kantin yang terlatak didalam lingkup sekolah tersebut. Akan tetapi pada masa pandemi ini semua orang yang berjualan dikantin sekolah tidak dipebolehkan jualan didalam sekolah, namun masih ada yang jualan walaupun diluar sekolah dekat dengan pagar sekolah. Sedangkan untuk taman bermain dan taman baca, di sekolah ini belum memiliki hal itu, mungkin dikarenakan lahan untuk membuat taman bermain dan teman baca yang tidak ada. Untuk itu anak lebih sering bermain ke katin, dan dilapangan saja bersama teman-temannya. Karena lahan kosong pada sekolah ini sangat bayak. Dan untuk WC siswa terlihat tidak terawat dan tidak nyaman untuk digunakan sedangkan WC guru bersih dan terawat.

Jadi dapat dibahas, bahwa dengan adanya lingkungan yang nyaman dan kondusif dapat meningkatkan motivasi belajar siswa sekolah dasar di kelas V SDN 007 Suka Maju, akan tetapi didalam kondisi lingkungan sekolah ini tidak terdapat masalah yang mana ini membuktikan bahwanya kondisi lingkungan sekolah yang ada di SDN 007 Suka Maju tidak mempengaruhi motivasi belajar siswa kelas $\mathrm{V}$.

\section{c.Relasi Guru Dengan Siswa}

Berdasarkan yang dikemukakan oleh Slameto (2018:66) mengatakan bahwa pada proses belajar mengajar terjadi antara guru dengan siswa proses tersebut juga dipengaruhi oleh relasi yang ada dalam 
proses itu sendiri. Jadi cara belajar siswa juga dipengaruhi oleh relasi dengan guru. Didalam situasi formal, yakni dalam usaha guru mendidik dan mengajar anak dalam kelas, guru harus sanggup menunjukkan kewibawaan atau otoritasnya. Artinya, ia harus mampu mengendalikan, mengatur, dan mengontrol kelakuan anak. Kalau perlu, ia dapat menggunakan kekuasaanya untuk memaksa anak belajar, melakukan tugasnya, atau mematuhi peraturan. Dengan kewibawaan yang ia miliki, ia menegakkan disiplin demi kelancaran proses belajar mengajar. dapat dilihat dari dokumentasi, observasi dan wawancara yang dilukukan dikelas V SDN 007 Suka Maju sebagai berikut ini:

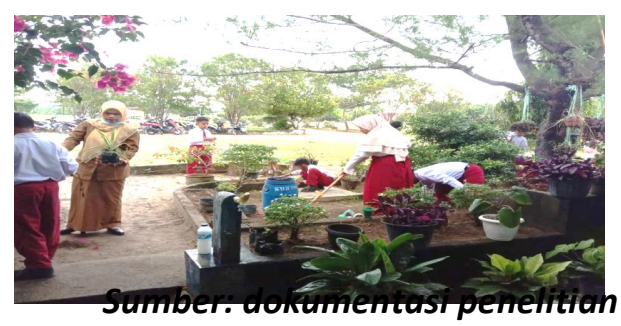

Gambar.IV.5

Kedekatan antara guru dan siswa

Menunjukkan bahwasanya interaksi atara guru dengan siswa sudah terjalin bagus, dimana ini dibuktikan pada saat observasi guru sudah ada yang banyak memberikan motivasi pada sat proses pemeblajran berlangsung walaupun diSDN 007 suka maju masih ada guru yang sangat cuwek terhadap murinya akan tetapi guru tersebut berusaha selalu memberikan contoh yang baik kepada siswanya, diluar kelas guru selalu menasehati siswanya yang melanggar peraturan sekolah. Kebiasaan seperti ini berdampak positif terhadap perkembangan siswa. Siswa semakin dekat dengan guru dan guru juga semakin dekat dengan siswanya.

observasi dan wawancara penelitian mengungkapkan bahwa terdapat korelasi yang positif antara interaksi guru dan siswa dengan motivasi belajar siswa V SDN 007 Suka Maju yang mana guru berusaha dekat dengan siswa dengan cara selalu memberikan semangat berupa pujian-pujian, Anak-anak secara langsung mengharapkan guru yang berwibawa dapat bertindak tegas untuk menciptakan suasana disiplin.

Jadi dapat disimpulkan bahwa relasi siswa dan guru dikelas V SDN 007 Suka Maju tidaklah bermasalah dengan adanya hasil dapat diambil kesimpulan bahwasanya faktor relasi siswa dengan guru tidak lah mempengaruhi motivasi belajar siswa.

\section{d.Relasi Siswa Dengan Siswa}

Berdasarkan teori yang dikemukakan oleh Slameto (2018:66) Siswa yang memiliki sifat atau tingkah laku yang kurang menyenangkan teman- temannya, mempunyai rasa rendah diri, atau sedang mengalami tekanan batin tertentu, akan dijauhi oleh teman-temanya maka akibatnya belajarnya akan terganggu. Dengan demikian, motivasi untuk belajar pun berkurang dan malas untuk masuk sekolah dengan berbagai alasan. Dari hasil penelitian yang dilakukan peneliti dapat dilihat dari dokumentasi, observasi dan wawancara yang dilukukan dikelas V SDN 007 Suka Maju sebagai berikut ini;

Sumber: dokumentasi penelitian

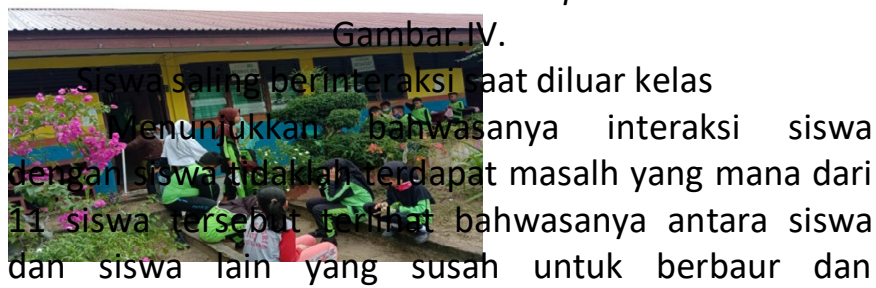
bergabung dengan siswa lainya hanya 1 orang saja dan siswa yang laianya berusaha untuk membawa siswa tersebut untuk selalu bergabung dengan mereka semua. Hasil observasi tersebut diperkuat dengan dilakukanya wawancara terhadap narasumber bahwa memang masih ada siswa yang suka menyendiri dan susah bergaul dengan temen-temennya akan tetapi hasil belajar siswa tersebut sangatlah memuaskan dibuktikan siswa tersebut masuk kedalam 5 besar yang ada dikelas tersebut.

Jadi dapat dismpulkan bahwasanya relasi siswa dengan siswa di kelas V SDN 007 Suka Maju tidak lah bermasalah walaupun masih ada siswa yang belum bisa bergabung dengan temannya baik didalam proses pembelaajran maupun diluar pembelajaran, namun itu tidak mempengaruhi motivasi belajar siswa tersebut yang mana terlihat pada saat peneliti observasi siswa tersebut ikut aktif saat proses pembelajaran berlangsung. Akan tetatapi siswa yang lain juga berusaha untuk selalu membawa siswa tersebut untuk ikut bergabung dengan teman-teman yang lainya.

\section{e.Alat Pelajaran atau Media Belajar}

Media pembelajaran adalah segala bentuk dan saluran yang digunakan oleh seorang guru untuk menyalurkan pesan atau informasi belajar berupa materi pembelajaran dengan memberikan kesempatan kepada siswa untuk memperoleh pengetahuan, keterampilan dan sikap. Media pembelajaran sangat berguna bagi siswa agar siswa mengetahui kegunaan media dalam proses belajar mengajar, yakni dengan memperhatikan prinsip- 
prinsip media yang ada. Berdasarkan hasil observasi, wawancara,dan dokumentasi didaptkan bahwasanya:

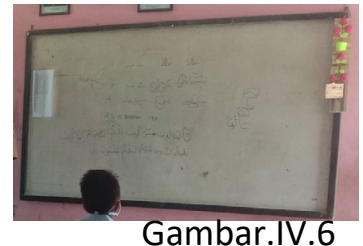

Media pembelajaran

Berdasarkan hasil observasi yang didapatkan bahwasanya guru kelas V SDN 007 Suka Maju sudah mengunakan media pemebaljaran namun hanya berupa buku pembelajran pegangan guru dan siswa, dan ada juga guru yang mengunakn gambar yang bersumber dari internet, dan ini membuat siswa tidak termotivasi ssat proses pembelajran berlangsung namun pada saat ada guru yang mnegunakan media nyata yang berupa bola kaki pada ssat pembelajran olahraga disitu terlihat siswa antusias saat proses pemebalajran. Yang mana dengan adanya hasil observasi tersebut membuktikan bawasanya salah satu yang mempengaruhi motivasi siwa kelas V SDN 007 Suka Maju terletak pada media pemeblajran yang digunakan guru. Dari hasil observasi tersebut dapat diperkuat lagi dengan adanya wawancara dengan para narasumber yang mana guru guru tersebut mengemukakan bahwasanya mereka memang mengunakan media belajar akan tetapi hanya berupa papan tulis dan buku LKS dan buku pegangan guru.

ini sesuai dengan teori yang dikemukakan oleh Gangne (2002:4) bahwasanya media belajar berupa alat yang secara fisik digunakan untuk menyampaikan isi materi pembelajaran yang terdiri dari, antara lain: buku, tape-recorder, kaset, video kamera, video recorder, film, slide (gambar bingkai), foto, gambar, grafik, televisi, dan komputer. Berikut ini akan diuraikan klasifikasi Media Pembelajaran menurut taksonomi Leshin, dkk.

Dari banyak nya media pembelajaran yang ada guru hanya mengunakan buku dan papan tulis yang mana membuat siswa kurang termotivasi dalam belajar, seharusnya sebagai guru kita harus menggunakan media yang kreatif yang membuat siswa antusias dan termotivasi dalam belajar dan membuat kita sebagai guru menjadi kreatif dan disenangi oleh siswa-siswa yang ada disana.

Jadi dapat disimpulkan dari hasil observasi, wawancara dan dokumentasi membuktikan bahwasnya media pembelajaran adalah salah satu yang mempengaruhi motivasi belajar siswa kelas V SDN 007
Suka Maju, media pembelajaran guru di SDN 007 Suka Maju kurang lah kreatif dan bervariasi yang mengakibatkan siswa kurang termotivasi saat pembelajaran berlangsung.

\section{Motivasi Belajar}

\section{a. Adanya Keinginan dan Hasrat untuk berhasil dalam Belajar}

Berdasarkan uraian yang telah disampaikan sebelumnya pada bagian hasil terlihat pada poin secara internal yang berupa adanya keinginan dan hasrat untuk berhasil siswa menunjukkan bahwasanya masih banyak siswa yang kurang bersemangat untuk mengerjakan tugas-tugas yang telah diberikan guru, responden menjawab Siswa selalu berusaha sendiri dan mengerjakan tugas-tugas pelajaran diberikan guru dari 11 siswa hanya sekitar barisan depan saja yang selalu bersemangat, sering menjawab pertanyaan dari guru dan juga masih banyak yang jarang dan tidak pernah mengerjakan tugas-tugas. padahal salah satunya yang dapat mendorong siswa untuk termotivasi terdapat didalam internal siswa ini sesuai dengan yang disampaikan Eveline Siregar dan Hartini Nara bahwasanya (2004:50) motivasi intrinsik memiliki kontribusi yang lebih kuat dibanding motivasi ekstrinsik. Motivasi intrinsik meliputi semangat dalam mengikuti proses pembelajaran, keaktifan siswa dalam mengikuti proses pembelajaran, kesadaran akan pentingnya menguasai dan memahami materi pelajaran, kemauan untuk memperoleh nilai di atas KKM, dan semangat belajar siswa.

Dari hasil analisis, menunjukkan bahwa pada saat akan melaksanakan pembelajaran, terlihat guru memberikan arahan kepada siswa untuk meningkatkan motivasi belajarnya. Meningkatnya motivasi belajar siswa yang terbukti dengan lebih meningkatnya semangat belajar siswa yang ditunjukkan dengan semakin aktif siswa dalam mengikuti proses pembelajaran dan kemauan siswa untuk selalu memperhatikan penjelasan guru serta semangat siswa untuk mencapai nilai

Jadi dapat disimpulkan bahwa motivasi belajar merupakan keseluruhan daya penggerak psikis dalam diri siswa yang mampu menimbulkan kegiatan belajar, menumbuhkan gairah, perasaan senang, dan semangat untuk belajar. siswa dengan motivasi belajar yang kuat akan mencurahkan perhatian, bekerja keras dan konsisten dalam kegiatan belajarnya. Dari hasil penelitian yang telah penulis lakukan maka dapat disimpulkan bahwa motivasi siswa dalam belajar yang 
ditandai dengan keinginan untuk berhasil sudah tergolong tinggi.

\section{b. Adanya keinginan, semangat dan kebutuhan dalam belajar}

Berdasarkan observasi dan wawancara yang didapatkan Berdasarkan internal dalam diri siswa yang berupa adanya keinginan, semangat dan kebutuhan dalam belajar siswa masih ada kalanya mereka tidak semangat dalam belajar, akan tetapi ketika guru mengunakan media pembelajran yang menarik disitu siswa terlihat termotivasi untuk ikut serta dalam belajar. ini sesuai dengan teori yang disampaikan dengan penelitian Retnowati (2017:02) mempunyai dorongan dan kebutuhan dalam belajar, yaitu selalu mempunyai kemauan untuk belajar yang meliputi selalu membaca buku yang ada hubungannya dengan materi pelajaran, dan selalu memanfaatkan waktu luang untuk membaca buku pelajaran; selalu disiplin yang meliputi selalu berangkat ke sekolah tepat waktu, selalu mengumpulkan tugas tepat waktu, dan tidak menunda-nunda dalam mengerjakan tugas; selalu bertanggung jawab terhadap tugas yang diberikan yang meliputi selalu mengerjakan tugas/PR yang diberikan oleh guru, dan tugas/PR selalu dikerjakan sendiri; selalu sadar akan pentingnya pengetahuan yang meliputi selalu memahami materi pelajaran yang dipelajari sendiri dan dijelaskan oleh guru.

Pada aspek siswa membaca materi pelajaran terlebih dahulu sebelum masukk kelas menunjukkan bahwa hanya ada 1 atau 2 siswa saja yang membaca materi pelajaran selebihnya hanya bermain dan bercerita, yang mana ini juga membuat kelas menjadi ribut. Hasil observasi ini juga dikuatkan dengan hasil wawancara yang penulis lakukan dengan para narasumber siswa yang termotivasi mambaca materi pelajaran dahulu sebelum pembelajaran dimulai hanya 1-2 orang saja yang mana ini membuktikan masih banyak dalm diri siswa yang belum termotivasi untuk membaca buku terlebih dahulu sebelum pembelajaran dimulai. Ini sesuai dengan teori yang dikatakan Oemar Hamlik (2010:61) mengemukakan bahwa motivasi Mendorong timbulnya kelakuan atau suatu perbuatan Artinya tanpa adanya motivasi maka tidak akan timbul sesuatu perbuatan. Motivasi berfungsi sebagai pengarah. Artinya mengarahkan perbuatan kepencapaian tujuan yang diinginkan Motivasi sebagai penggerak. Besar kecilnya motivasi akan menentukan cepat atau lambatnya suatu pekerjaan.

Jadi dapat disimpulkan berdasarkan fungsi motivasi diatas dapat dipahami bahwa fungsi dari motivasi belajar yaitu sebagai pendorong, pengarah dan penggerak bagi siswa untuk melakukan kegiatan atau aktivitas belajar dengan baik. Sehingga tujuan yang diinginkan akan tercapai seperti mendapatkan hasil belajar yang memuaskan. Berdasarkan hasil penelitian yang telah penulis lakukan maka dapat disimpulkan bahwa motivasi siswa pada tahap indicator ini juga tergolong kurang.

\section{c.Memiliki Harapan Dan Cita-Cita Dimasa Depan}

Berdasarkan hasil analisis yang telah dilakukan didapatkan bahwasanya pada aspek internal dalam diri siswa yang berupa memiliki harapan dan cita-cita masa depan siswa menunjukkan bahwa sebagian dari 11 siswa belum belajar dengan sungguh-sungguh untuk mendapatkan nilai baik, dan Pada aspek siswa membaca buku yang bersangkutan dengan materi pelajaran agar dapat mengerjakan tugas yang diberikan guru dengan baik menunjukkan bahwa 2 siswa responden menjawab Siswa selalu membaca buku yang bersangkutan dengan materi pelajaran agar dapat mengerjakan tugas yang diberikan guru dengan baik, ada juga siswa yang sering menjawab dan ada juga siswa yang tidak pernah membaca buku yang bersangkutan. Berdasarkan indikator yang dikemukakan Uno (23:2019) salah satu tanda siswa termotivasi dalam belajar adalah cita cita dimasa depan yang mana indikator ini termasuk kedalam indikator internal yang berada didalam diri siswa, dimana siswa belajar dan sungguh-sungguh untuk mendapatkan nilai baik.

Yang mana sadirman (2016:84) mengemukakan bahwa motivasi Mendorong manusia untuk berbuat, jadi motivasi dalam hal ini merupakan motor penggerak dari setiap kegiatan yang akan dikerjakan, Menentukan arah perbuatan, yakni kearah tujuan yang hendak dicapai. Dengan demikian motivasi dapat memberikan arah dan kegiatan yang harus dikerjakan sesuai dengan rumusan tujuannya, Menyeleksi perbuatan, yakni menentukan perbuatan-perbuatan apa yang harus dikerjakan yang serasi guna mencapai tujuan, dengan menyisihkan perbuatan-perbuatan yang tidak bermanfaat bagi tujuan tersebut

\section{d. Adanya penghargaan dalam belajar}

Berdasarkan observasi dan wawancara didapatkan bahwasanya siswa sangat termotivasi dalam belajar secara eksternal sesuai yang disampaikan oleh Uno (2019:23) salah satu tanda siswa termotivasi dalam belajar adalah adanya penghargaan dalam belajar yang mana indikator ini merupakan indikator yang tergolong dalam indikator ekternal, dimana siswa memberikan pendapat untuk mendapatkan pujian dari 
guru Siswa berusaha menjawab pertanyaan yang diberikan untuk mendapatkan nilai terbaik dari guru.

Dari aspek Siswa memberikan pendapat untuk mendapatkan pujian dari guru. menunjukkan bahwa dari 11 siswa responden ada sebagaian siswa menjawab selalu memberikan pendapat untuk mendapatkan pujian dari guru, dan ada juga yang menjawab sering dan untuk jarang menjawab juga ada. Hasil observasi ini juga dikuatkan dengan hasil wawancara yang penulis lakukan dengan para narasumber bahwasanya siswa sangat semangat mengikuti pembelajaran ketika mereka memperoleh acungan jembol dari guru, memperoleh hadiah dari guru yang berupa pujian dari guru tersebut, siswa terlihat sangat antusias dalam belajar yang mana ini terihat dari salah satu siswa yang ada disana adalah siswa $\mathrm{R}$ yang mana siswa tersebut lemah akan pelajaran akan tetapi ketika guru memberikan hadiah siswa tersebut menjadi ikut serta dala pembelajran berlangsung, ini sesuai dengan penelitian Syaiful (2020:120) bahwasanya hadiah dapat menjadi motivasi yang kuat, dimana siswa tertarik pada bidang tertentu yang akan diberikan hadiah.Tidak demikian jika hadiah diberikan untuk suatu pekerjaan yang tidak menarik menurut siswa.

Jadi dari penelitian yang telah penulis lakukan maka ditemukan bahwa memberikan hadiah dengan baik kepada siwa yaitu apresiasi berupa hadiah makanan dan pena kepada siswa, jadi dengan memperhatikan siswanya tersebut dapat membuat siswa menjadi tertarik untuk belajar sehingga mendapatkan hasil yang maksimal

\section{e.Adanya ketertarikan yang menarik dalam belajar}

Berdasarkan observasi dan wawancara didapatkan bahwasanya siswa sangat termotivasi dalam belajar secara eksternal sesuai yang disampaikan oleh Uno (2019:23) Salah satu tanda siswa termotivasi dalam belajar adalah adanya penghargaan dalam belajar yang mana ini tergolong kedalam indikator ekternal siswa, dimana siswa antusias mengikuti pelajaran dengan baik dari awal sampai akhir, serta siswa selalu aktif dalam proses pelajaran.

Dilihat dari aspek Siswa antusias mengikuti pelajaran dengan baik dari awal sampai akhir. menunjukkan bahwa; 11 responden sebagian siswa menjawab selalu antusias mengikuti pelajaran dengan baik dari awal sampai akhir. Ketertarikan siswa makin kuat ketika guru mengunakan media dan model pembelajaran yang menarik, ini sesuai dengan teori
Syah (2020:134) mengemukakan bahwa Guru merupakan peranan penting dalam mempengaruhi motivasi belajar siswa melalui metode pengajaran yang digunakan dalam penyampaian materi pelajaran. Pada pelajaran tertentu guru harus menggunakan metode mengajar yang sesuai dengan materi yang akan disampaikan karena hal ini sangat berpengaruh terhadap salah satu tujuan dari belajar sendiri.

Hasil observasi ini juga dikuatkan dengan hasil wawancara yang mana narasumber mengatakan bahwasanya siswa disini sudah lumayan agak bagus dan aktif. siswanya kebanyakana siapa yang serius belajar aja ada juga mereka sulit sekali untuk bertanya disini motivasi mereka belajar tergantung pada materi pelajaran juga kalau materinya menerikbanyak dianatara mereka yang bertanya.

\section{f. Adanya lingkungan yang kondusif untuk belajar dengan baik}

Berdasarkan observasi dan wawancara dengan didapatkan bahwasanya indikator ekternal yang berupa adanya lingkungan yang kondusif untuk belajar dengan baik sudah lah baik ini dibuktikan dari hasil analisis adanya kipas angin yang berjumlah dua pada setiap kelas, adanya lubang-lubang udara yang membuat kelas menjadi lebih nyaman, ini sesuai dengan yang dipaparkan oleh Ki Hadjar Dewantara, sekolah adalah tempat belajar yang menyenangkan. Oleh karena itu, sekolah haruslah disediakan fasilitas serta sarana yang dapat menunjang proses belajar para siswa agar pencapaian jutujuan dalam belajar tercapai. Ini sesuai penelitian Mona (2017:102) bahwasanya Sarana pendidikan merupakan semua fasilitas yang diperlukan dalam proses belajar mengajar baik yang bergerak maupun tidak bergerak agar pencapaian tujuan pendidikan dapat berjalan dengan lancar. Sedangkan yang dimaksud dengan prasarana pendidikan adalah fasilitas yang secara tidak langsung menunjang jalannya proses pendidikan atau pengajaran, seperti halaman, kebun, taman sekolah, jalan menuju sekolah.

Terlihat pula didepan kelas terdapat taman yang indah serta halaman yang luasa yang membuat siswa betah untuk selalu berada disekolah, hal ini sesuai dengaan penelitian Ifan bahwasanya Tamanisasi merupakan salah satu kegiatan yang menyediakan fasilitas untuk mendukung dalam proses pembelajaran bagi siswa. Tamanisasi sekolah mempunyai beberapa manfaat, bagi sekolah, yaitu untuk memperindah lingkungan sekolah dan memberi rasa sejuk, karena dikelilingi oleh tanaman yang indah. Taman sekolah dapat memberi motivasi belajar kepada para siswa karena dengan lingkungan sekolah yang indah dan 
sejuk, mereka akan merasa betah dan bersemangat untuk belajar.

Indikator motivasi belajar yang dikemukakan Uno (2019:23) salah satu tanda siswa termotivasi dalam belajar adalah adanya penghargaan dalam belajar yang mana ini termaksut kedalam indikator ekternal motivasi belajar siswa, dimana siswa menempatkan benda-benda dalam kelas dengan rapi serta Siswa menghias ruangan yang digunakan dengan benda yang dapat dijadikan media dalam belajar.

Jadi berdasarkan penjelasan diatas dapat disimpulkan bahwa agar siswa memiliki motivasi yang tinggi didalam pelajaran, siswa harus memiliki minat dan juga reaksi, seperti rasa senang, mendengarkan apa yang disampaikan guru pada saat pelajaran berlangsung, dan mengerjakan tugasdengan senang.

\section{Simpulan}

Berdasarkan hasil dan pembahasan yang telah diuraikan pada bab sebelumnya dapat disimpulkan bahwa faktor lingkungan sekolah yang mempengaruhi motivasi belajar siswa pada siswa kelas V SDN 007 Suka Maju, terdapat lima faktor lingkungan sekolah yaitu: metode mengajar, keadaan gedung, relasi guru dengan siswa, relasi siswa dengan siswa, alat pembelajaran atau media belajar. Dari kelima faktor yang mempengaruhi motivasi belajar siswa terdapat dua faktor yang mempengaruhi motivasi belajar siswa yaitu faktor metode mengajar, dan media belajar.

\section{Daftar Pustaka}

Akhiruddin, Dkk ,(2019). Belajar Dan Pebelajaran. Makasar : Cv. Cahaya Bintang Cemerlang

Alim, Melvi Lesmana. Upaya Meningkatkan Kemampuan Fisik Motorik Kasar Anak Melalui Kegiatan Melambungkan Dan Menangkap Dengan Berbagai Media Anak Usia Dini Di TK Al-Fajar Pekanbaru. Jurnal Obsesi: Jurnal Pendidikan Anak Usia Dini, 2015, 1.2: 83-93.

Ananda, Rizki. Penerapan Metode Mind Mapping untuk Meningkatkan Kemampuan Berpikir Kreatif Siswa Sekolah Dasar. Edukatif: Jurnal Ilmu Pendidikan, 2019, 1.1: 1-10

Asrori, (2020). Psikologi Pendidikan Pendekatan Multidisipliner.Jawa Tengah : Cv. Pena Persada

Hanafiah \& Suhana. (2012). Konsep Strategi Pembelajaran.Bandung: PT Refrika Aditama.

Hasbullah. (2013). Dasar-Dasar Ilmu Pendidikan. Jakarta: Pt. Raja GrafindoPersada.
Indonesia, P. R. (2003). Undang-undang Republik Indonesia nomor 20 tahun 2003 tentang sistem pendidikan nasional. Departemen Pendidikan Nasional.

Iskandar. (2008). Metodologi Penelitian Pendidikan Dan Sosial (Kuantitatif Dan Kulitatif). Jakarta: Gaung Persada Press.

Iskandar. (2012).Psikologi Pendidikan Sebuah Orientasi Baru. Jakarta:Referensi.

Kompri. (2014). Manajemen Sekolah. Bandung: Alfabeta

Musaheri.(2007). Pengantar pendidikan. Yogyakarta: IRCiSoD.

Nazir, M (2012). Metode Penelitian. Bogor: Penerbit Ghalia Indonesia

Nana, SS. (2009). Landasan psikologi proses pendidikan. Bandung: RemajaRosdakarya

Nurfirdaus, N., \& Hodijah, N. (2018). Studi Tentang Peran Lingkungan Sekolah danPembentukan Perilaku Sosial SiswaSDN3 Cisantana. EDUCATOR, 4(2), 113-129.

Uhbiyati, A,N. (2003). Ilmu pendidikan. Jakarta: Rineka Cipta.

Sardiman. (2016). Interaksi Dan Motivasi Belajar Mengajar. Jakarta: Pt Raja Grafiondo Persada.

Slameto. (2018). Belajar Dan Faktor-Faktor Yang Mempengaruhi. Jakarta :Rineka Cipta

Sumianto. Penerapan pendekatan matematika realistik (PMR) untuk meningkatkan hasil belajar matematika siswa kelas V Al-Azim SDIT Raudhatur Rahmah Pekanbaru. Jurnal Basicedu, 2018, 2.1: 49-56.

Sugiyono. (2018). Metode Penelitian Kuantitatif Kualitatif Dan R\&D. Bandung:Alfabeta.

Tatang. (2015). Manajemen penedidikan berbasis sekolah. Bandung: pustaka setia

Uno H.B. (2019). Teori Motivasi Dan Pengukurannya Analisis Di Bidang Pendididikan. Jakarta: Bumi Aksara

\section{Profil Penulis}

Nurul Sa'adah : Lahir di Dolok Merawan, 20 Januari 1999. Asal sekolah, lulus dari TK Dahliah di Desa Suka Maju,kemudian lanjut ke SDN 007 Suka Maju, MTK Jabal Nur Kandis, dan mejanjukan ke MA Miftahul Hidayah Kemudian melajutkan pendidikan SI di Universitas Pahlwan Tuanku Tambusai di Bangkinang dengan menagambil fakultas ilmu pendidikan prodi S1 Pendidikan Guru SekolahDasar. 